\title{
DISSERTAÇÓES DE MESTRADO
}

\section{ALMEIDA, Marcos Alves de}

Geologia da Formação Agua Clana na Regiäo de Araçaba, SP. 17 de abril. 194p. 1 vol. Orientador: José Moacyr Vianna Coutinho.

Resumo: $\quad \mathrm{Na}$ região de Araçarba (SP) ocorrem dois litocipos, referidos às formaçóes Água Clara e Córrego dos Marques. Essas unidades foram afetadas por sucessivas fases de deformaçáo e metamorfismo e por trếs grandes intrusōes de rochas ígneas.

A Formaçăo Água Clara caracteriza-se por apresentar mudanças faciologicas de leste para oeste. A leste afloram calcio-silicaticas alternadas com rochas metacarbonáticas impuras. Rumo a oeste, há variạ̧óes dos constituintes litologicos, com o aparecimento de intercalap̧óes, nas rochas calcio-silicáticas, de rochas xistosas, quartziticas e metabasticas.

Os metacarbonatos expostos a leste foram afetados por metamorfismo regional dinamotermal, em grau médio, a zona metamórfica da actinolita e os meta-sedimentos, com vulcánicas associadas, do lado oeste, por metamorfismo de grau médio da zona metamorfica do diopsidio. Haveado, assim, um aumento de grau metamorfico de leste para oeste.

Associado a este evento de metamorfismo regional dinamotermal, ocorreu o desenvolvimento do bandamento composicional de transposigäo $\left(\mathrm{S}_{\mathrm{n}}\right)$ da fase de deformaçäo $\mathrm{F}_{\mathrm{n}}$, gerada por cisalhamento simples, de baixo ângulo e de caráter dóctil. As evidencias mais marcantes desta fase de deformaçăo sāo: presenģa de dobras intrafoliais, "boudinage" de camadas, mais competentes, estiramento de gräos minerais, bem como a presença de dobras em bainha.

Uma segunda fase de deformaçäo $F_{n+1}$ deseavolveu o bandamento de transposiçăo $S_{n+1}$ que se sobrepos à superficie anterior $\mathrm{S}_{\mathrm{n}}$. E uma foliaçăo de transposigâo de alto ângulo que afetou generalizadamente os meta-sedimentos da Formaçáo Água Clara. Associado a esta lase tardia de deformaçăo desenvolveu-se um segundo evento de metamorfismo regional, de caráter termal, evidenciado pelo aparecimento de actinolitas centimétricas. Esse metamorfismo está associado à intrusáo ignea que, devido aos movimentos gerados por cisalhamento simples, de bairo ângulo, da fase $\mathrm{F}_{\mathrm{n}}$, resultou na formaçăo de ortognaisses, expostos a oeste na área de estudo.

A seguir, como conseqüéncia dessa formaçăo progressiva da fase $\mathbf{F}_{\mathbf{n}+1}$, ocorreu o desenvolvimento de movimentaçóes sub-horizontais em zonas de cisalhamento de alto ângulo desenvolvidas tardiamente ("Shear Zones"), de uma fase de deformaçăo $\mathrm{F}_{\mathrm{n}+2}$, que dobrou e redobrou os metasedimentos Água Clara, gerando macrodobras $\mathrm{D}_{\mathrm{n}+2}$.

Inferior.

Considerou-se para a Formaçäo Agua Clara uma idade de deposiçảo no Proterozoico

Posteriormente, no Proterozbico Médio a Superior, houve a deposiçăo dos meta-sedimentos da Formação Corrego dos Marques, correlacionados aos meta-sedimentos dos grupos Itaiacoca e AçunguiSubgrupo Lajeado e Formaçăo Rio das Pedras/Perau.

A Formação Córrego dos Marques 6 constitúfla de meta-sedimentos predominantemente pelfiticos e químicos e localmente psamfticos. São filitos, cálcio-filitos e cálcio-xistos finos, calcários dolomíticos impuros, quartzosos, com intercalagües de quartzitos e metarenitos finos; localmente ocorrem 
metabasitos.

Estruturalmente identificaram-se tres fases de deformação denominadas de $F_{1}, F_{2}$ e $F_{3}$, sendo que as duas filtimas estão associadas ds duas últimas fases que afetaram as rochas da Formaçăo Água Clara, evidenciando um processo contínuo e progressivo de deformaçāo. O metamorfismo regional dinamotermal é de grau fraco, fácies xisto verde.

Intenso magmatismo ácido $\epsilon$ identificado na área, através das rochas Suíte Granítica Trés Corregos. Posteriormente, ocorreu novo magmatismo ácido caracterizado pelo Granito Apiaf. Atribuiramse idades do Proterozóico Superior ao Cambro-Ordoviciano para essas unidades.

E, finalmente, encerrando a etapa de transigáo da Plataforma Brasileira, ocorreram os grandes falhamentos transcorrentes, com destaque a falha Quarenta Oitava.

Abstract: Two lithotypes occur in the Araçafba region, in São Paulo State, attributed to Água Clara and Corrego dos Marques Formations. Both these units have been affected by several metamorphic and deformation events, plus the emplacement of three large intrusive igneous bodies.

In the east part of the area, the Água Clara Formation displays alternating calc-silicate and impure carbonatic rocks, affected by regional dynamothermal metamorphism corresponding to the actinolite zone. Schists, quartzites and metabasites interbedded with cale-silicate rocks add to these rocks in the west area. In this case they are metamorphosed in the diopside zone, thus characterizing an increasing degree of metamorphism toward the west direction.

Associated to this regional dynamothermal metamorphic event a compositional transposed layering has also developed $\left(\mathrm{S}_{\mathrm{n}}\right)$, corresponding to an episode of deformation $\left(\mathrm{F}_{\mathrm{n}}\right)$, caused by ductile lowangle simple shearing. The most remarkable evidences for this phase of deformation can be observed in different scales of approach stretching of mineral grains, intrafolial folds, sheet folds and boudinage of more resistant rocks.

A second phase of deformation $\left(F_{n+1}\right)$ caused the development of a compositional layering $\left(S_{n+1}\right)$, overprinted on the previous surface $\left(S_{n}\right)$. It is represented by a high-angle transposed foliation which affected the metasediments of the Água Clara Formation as a whole. Together with this late phase of deformation, a second episode of regional metamorphism of thermal character has developed, as displayed by centimetric actinolite crystals. This metamorphism is associated with igneous activity which resulted in orthogneisses, due to tectonic movements caused by simple low-angle shearing during the phase $\left(\mathrm{F}_{\mathrm{n}}\right)$.

Next, as a consequence of the progressive deformation of phase $\left(F_{n+1}\right)$, sub-horizontal movements affected the lately developed high-angle shear zones attributed to a $\left(F_{n}+2\right)$ phase, which folded and re-folded the metasediments of Água Clara Formation, thus originating macrofolds $\left(D_{n+2}\right)$.

The deposition of sediments which composes the Água Clara Formation is thought to be of Lower Proterozoic age, while those which formed the Corrego dos Marques Formation, would have been deposited in Middle to Upper Proterozoic. This Formation, as defined here, is correlated to the metasediments of Itaiacoca and Açungui Groups - Lajeado Subgroup and Rio das Pedras/Perau Formation.

The Corrego dos Marques Formation is made up mostly of pelitic (locally psamitic) and chemical metasediments: phyilites, calc-phyllites and fine-grained calc-schists, impure dolomitic limestones, interbedded with quartzites and fine-grained metarenites, and, locally, metabasites.

Three phases of deformation have been recognized $\left(F_{1}, F_{2}\right.$ and $\left.F_{3}\right)$, the last two of them being associated with the two last phases which affected the rocks of Agua Clara Formation. A progressive and continuous process of deformation is thus indicated. Regional dynamothermal metamorphism is weak, corresponding to the greenschist facies. 
Rocks of Trés Córregos Granitic Suite record an intense phase of acid magmatism, continued through the emplacement of Apiai Granite. The ages of theses units are supposed to range from Upper Proterozoic to Cambro-Ordovician.

The final events of the geologic evolution are connected to big transcurrent faults, among shich the Quarenta Oitava Fault is the most important. This tectonic activity represents the transitional stage, whose end resulted in the achievement of the Bravilian Platform.

\section{BOGGIANI, Paulo César}

Ambientes de sedimentaçẫo do Grupo Conumbá na regiāo central da Serra da Bodoquena, Mato Grasso do SuL 26 de junho. 91p. 1 vol. Orientador: Thomas Rich Fairchild.

Resumo: O Grupo Corumbá é formado por rochas carbonáticas associadas a terrígenos com provável idade vendiana, constituindo parte da Faixa Paraguai e se cstendendo sobre o Cráton Amazônico.

Neste trabalho, a Faixa Paraguai é considerada como Faixa de metassedimentos e sedimentos de idade cambriana a proterozóica superior, situada na borda do Cráton Amazônico, desde o vale do rio Apa até a regiáo do Alto Araguaia, $\mathrm{cm}$ Goiás. Na serra da Bodoquena, regiāo escollhida para estudo dos ambientes de sedimentação do Grupo Corumbá, foram individualizadas duas faixas paralelas denominadas zonas Interna $\mathrm{e}$ Externa, semelhante a procodimento já adotado na porção da faica aflorante no Estado de Mato Grosso.

A zona Interna, situada na parte leste da região estudada, é caracterizada por maior intensidade das deformaçóes tectônicas, onde as camadas apresentam-se falhadas e com dobras isoclinais. $\mathrm{Na}$ zona Externa, situada na porção oeste, as dobras sắo abertas e suaves.

Na zona Externa ocorrem trés fácies terrigenas (de conglomerados, de arcósios e de lamitos), associadas a cinco fácies carbonáticas: de grainstones com laminaçōes cruzadas, de margas e mudstones alternados, de mudstones pseudonodulares, de mudstones e de estromatólitos. As fácies terrígenas predominam na base $\mathrm{e}$ as carbonáticas no topo de sucessão estratigráfica de aproximadamente $180 \mathrm{~m}$ de espessura, onde se interpretou deposiçấo de fanglomerado seguida por transgressão em rampa carbonática aberta.

A zona Interna, por se encontrar mais tectonizada, apresenta estratigrafia de difícil definição e pouco controle de espessura de sedimentos. Nesta se concentram as ocorrências de rochas fosfáticas associadas a dolomitos e estromatolitos. As demais fácies encontradas são grainstones ooliticos, de brechas intraformacionais com clastos centimetricos discofides, de brechas com blocos e de mudstones dolomíticos, que sugerem ambientes de águas rasas, enquanto que fácies de lamitos e de mudstones calciticos corresponderiam a águas profundas. $\mathrm{O}$ contraste de profundidades sugere a ocorréncia de upwelling como possivel de fósforo para a origem dos depósitos fosfáticos.

A alternåncia de terrigenos e carbonatos, juntamente com a ocorrência de pseudomorfos de gipsita e de prováveis tepees, permite concluir que durante ao menos parte da deposiçäo do Grupo Corumbá o clima era árido a semi-árido.

Abstract: The Corumbá Group is made up of carbonate and terrigenous sediments of probable Vendian age that comprise part of the Paraguai belt and extend into the Amazon Craton. The Paraguai belt crops out along the margin of this craton as a band of sediments and metasediments of late Proterozoic to Cambrian age from the Apa Valley (Paraguay) to the Alto Araguaia region (State of Goiás). 
In the serra da Bodoquena (State of Mato Grosso do Sul), the region chosen for the study of sedimentary environments of the Corumbá Group, two parallel bands, designated the inner and outer zones, have been identified, much as other workers have done further north in the Paraguay belt in the State of Mato Grosso. The inner zone, situated in the eastern portion of the study area, is much more deformed than the outer zone, isoclinally folded and intensely faults beds being rather common. In the outer zone, more to the west, folds are open and gentle.

In the outer zone, three terrigenous facies, represented, respectively, by conglomerates, arkoses, and mudstones, are associates with five calcareous facies, characterized by cross-laminated grainstones, alternating marls and lime mudstones, pseudonodular lime mudstones, lime mudstones and silicified stromatolites. The terrigenous facies predominate at the base and the calcareous facies at the top of an approximately $180 \mathrm{~m}$ thick sequence. Sedimentation is interpreted as having begun with fanglomerate deposition followed by marine transgression and open carbonate ramp.

Tectonic complications make definition of the stratigraphy or even calculation of thickenesses much more difficult in the inner zone. It is within this zone, however, that phosphatic rocks are concentrated. Shallow-water deposition is suggested by facies characterized by oolitic grainstones, intraformational centimetric flat-pebble breccias, intraformational breccias with decimetric clasts and mudstones dolomitic, whereas deep-water condition are inferred from mudstones and lime mudstones facies in the extreme eastern portion of the area. This bathymetric setting comprises presumptive for upwelling as the source of phosphate in this zone.

The climate during at least part of Corumbá sedimentation may well have been semi-arid so arid, to judge from the alternation of terrigenous and carbonate facies and the presence of calcite pseudomorphs after gypsum and probable tepee structures in the carbonates.

\section{DINIZ, Hélio Nóbile}

Estudo hidrogeológico do Subgrupo Itararé no Médio Rio Tietê, Municipio de Tietê, SP. 14 de novembro. 116p. 1 vol. Orientador: Uriel Duarte.

Resumo: Os sedimentos da Formaçāo Tietê, do Subgrupo Itararé, do Grupo Tubarāo, têm uma primordial importancia nos locais onde afloram: a captação de água subterrânea para suprir a demanda das populações locais. As captaçōes de superfície, nestes locais, atualmente estão em desuso, face à intensa poluị̧áo dos mananciais, muitas vezes proveniente de outros municípios situados a montante. Esta poluiçāo É causada pelo lançamento de poluentes nos rios, sem qualquer tratamento, principalmente nas áreas urbanas dos municípios. Em conscquecencia, $\epsilon$ grande a procura de água subterrânca, tanto para abastecimento das populaçōes urbanas, quanto para o suprimento da demanda agrícola e industrial.

A variaçäo faciológica dos sedimentos glaciais do Subgrupo Itararé produz uma ampla faixa de vazōes nas captaçōes de água subterrânea e, frente às dificuldades para a prospeção da água subterrânea nestes sedimentos, deve-se empregar métodos avançados de pesquisa para avaliação do potencial hídrico subterrâneo e localizar melhor as futuras captaçôes.

O Instituto Geológico, graças a muitos anos de trabalho na área do Município de Tietê e regiöes circunvizinhas, acumulou dados que permitem um estudo cientifico amplo sobre a geologia e hidrogeologia local.

Este trabalho enfoca os aspectos geológicos regionais e locais, possibilitando uma ampla discussão sobre a faciologia dos sedimentos do Subgrupo Itararê na região do Medio Rio Tietê, no 
Município de Tiete, com especial atençăo aos sedimentos da Formaçăo Tietê, o aquifero local por excelência, e os aspectos qualitativos das águas subterrâneas.

Neste trabalho foram empregados métodos apropriados de pesquisa para a caracterizacảo hidrogeologica dos sedimentos e para o conhecimento do potencial de uso da água subterrânea. Estes metodos envolveram levantamentos geológicos, geral e de detalhe, estudos $\mathrm{e}$ interpretaģóes de dados hidrológicos, interpretaçăo de dados de ensaios de bombeamento em poços tubulares profundos e, estudos hidroguímicos $\mathrm{e}$ isotópicos visando caracterizar e definir a origem das águas subterrâneas.

Abstract: The sedimentary rocks of Tiete Formation from Itarane Subgroup of Tubarão Group have a great signifieance in the places where they outcrop. They are used to supply of groundwater the local inhabitants. The surface sources of water are not used in region as a consequence of the high pollution in the rivers, in most cases imported from municipalities situated upstream. This fact result from the throwing of effluents into rivers in urban areas of the municipalities. In consequence, is great the increase of groundwater searching.

The facies variation of glacial sediments of Itarare Subgroup occasion a large range of yields value in groundwater wells and because of difficulties for prospect the groundwater from this sediments, we have to utilize advanced methods of search for evaluating the groundwater potential.

The Instituto Geologico has been working for several years in the Tietê municipality and in it's neighborbood and it has accumulated a lot of data which make it able to do a very extensive geologic and hydrogeologic scientific study.

The present work intend for stablish the regional and local geologic aspects and it allow a extensive debate about the facies of the Itarare sedimentary rocks with especial attention to sediments of Tiete Formation which is the aquifer local for excellence, and the aspects qualitatives of groundwater in this sediments.

This work intends to use the most suitable methods of searching to characterize hydrogeologic data of sediments and for knowledge groundwater use potential. These methods have dealt with geologic and hydrogeologic field studies, the interpretation of pumping data originated from deep wells, and isotopic and hydrochemical studies to have in view stablish the origin of the groundwater and it's chemical feature.

\section{ENS, Hendrik Herman}

Petrogenese dos escarnitos de Itaoca, vale do Ribeira, SP. 10 de maio. 172p. 1 vol. Orientador: José Moacyr Vianna Coutinho.

Resumo: Os escarnitos estudados ocorrem no interior e bordas de enclaves e possiveis tetos pendentes metassedimentares que afloram na porçäo central do Macigo Granítico de Itaoca. Pela ação térmica e emissäo de fluidos aquosos do corpo magnático as rochas metassedimentares dos enclaves, assim como as encairantes, originaram hornfels diversos, mármores e escarnitos.

Foram identificados na área dois tipos distintos de escarnitos, denominados respectivamente de granada-salita escarnitos e granada-wollastonita escarnitos.

Os granada-salita escarnitos ocorrem em zonas métricas ao longo dos contatos entre granitoides e mármores, constituindo-se essencialmente de clinopiroxênios (salita-ferrosalita) com bandas e veios granatiferos (grossulária-andradita). Fases minerais tardias (epidoto, albita, calcita) ocorrem 
substituindo principalmente as granadas.

Os granada-wollastonita escarnitos desenvolveram-se como espessos pacotes entre os mármores e hornfels pelíticos: constituem-se de wollastonita, grossulária e algum diopsídio. Localmente as granadas apresentam-se bastante albitizadas e vesuvianitizadas.

2 kbar.

O metamorfismo de contato atingiu temperaturas superiores a $650^{\circ} \mathrm{C}$ e pressão em torno de

Formaram-se inicialmente, por bimetassomatismo (difusâo), ainda a temperaturas elevadas, da ordem de $600^{\circ} \mathrm{C}$, em condiçōes redutoras, salita/ferrosalita escarnitos. Com o progressivo abaixamento da temperatura os flúdos infiltrantes tornaram-se oxidantes e eariquecidos em alumina e slica, promovendo a oxidação dos piroxénios e formação de bandas granatiferas. Nesta fase, a temperaturas entre 450 e $550^{\circ} \mathrm{C}$, formaram-se os granada-wollastonita escarnitos, em ambiente distal, por açào dos fluidos já empobrecidos em ferro.

Durante a fase retrógrada formaram-se albita, epídoto e vesuvianita pela destruiçáo da granada e ocorreu a deposição de sulfetos. Por áltimo, na fase hidrotermal finah, os fluidos tornaram-se enriquecidos em $\mathrm{CO}_{2}$, propiciando a carbonataçăo dos minerais formados anteriormente e a formaçâo de veios e vênulas de apofilita e prehnita.

Abstract: The skarns under consideration can be found inside or at the rims of metasedimentary inclusions and, conceivably, roof pendants, which outerop in the central part of the Itaoca granite pluton. Such skarms, together with a variety of hornfels and marbles were formed by thermal metamorphism and outward diffusion of aqueous fluids from the magmatic body.

Garnet-salite and garnet-wollastonite are the two main assemblages making up Itacca

skarns.

Garnet-salite skarns occur in zones of metric thickness along the granitoid-marble contact and consist of essential clinopyroxene (salite-ferrosalite) and garnet-rich (grossular-andradite) bands and veins. Late mineral phases (epidote, albite, calcite) may replace carlier ones (garnet mainly).

Garnet-wollastonite skarn occur as thick bodies between marble and pelitic hornfels and consist of essential wollastonite and grossular with some diopside. Garnet will, locally, exhibit a high degree of replacement by albite and vesuvianite.

Contact metamorphism reached its peak at temperatures above $650^{\circ} \mathrm{C}$ and pressures around

2 kbar.

Salite/ferrosalite skarns were formed by bidirectional metassomatism at the still elevated temperatures of about $600^{\circ} \mathrm{C}$ under reducing conditions. In the progressively cooling environment the infiltrating fluids became more and more oxidizing and enriched in alumina and silica, a fact which resulted in the oxidation of pyroxenes and formation of garnet bands. At this stage and temperatures between 450 and $550^{\circ} \mathrm{C}$, distal garnet-wollastonite skarns were formed by metassomatic processes linked to iron depleted fluids.

In a retrograde stage, garnet was destroyed and replaced by albite, epidote and vesuvianite, sulphides being deposited.

Finally, during the last hydrothermal stage, $\mathrm{CO}_{2}$-rich fluids furthered the carbonation of early minerals and the formation of apophyllite-prehnite venules. 
FASSBINDER, Elvo

Analise estrutural da Falha da Lancinha, Estado do Paraná. 11 de maio. 165p. 1 vol. Orientador: Georg Robert Sadowski.

Resumo: A estruturaçäo do Lineamento Além Parafba-Cubatăo Lancinha ocorreu em dois eventos distintos: Cubatáo e Lancinha.

O Evento Transcorrente Cubatão, atuante em rochas gnáissicas, mostra a presença de rochas milonitticas e blastomiloníticas, com metamorfismo do fácies anfibolito e deformaçôes essencialmente docteis associadas.

A reativaçāo de antigos planos de fraqueza gerados no Evento Cubatăo, levaram à deformaçáo dos metassedimentos Açungui sobrepostos, com a instalação de estruturas secundárias previstas no Modelo de Riedel, como dobras escalonadas, falhas sintéticas e antitéticas, além de fraturas do tipo Y(D), X e T. Associam-se a estas estruturas um generalizado fraturamento e esporádicas brechas, alem de lenticularizaçōes e constriçcōes de camadas litológicas. Estas deformaçōes geradas no nivel estrutural mEdio, caracterizam o Evento Transcorrente Lancinha.

A presença de esforços transpressionais alçaram o Núcleo Betara, e expuseram cisalhamentos transcorrentes dúcteis, rúpteis-dúcteis, além de deformaçöes rúpteis. Além disso, estes esforços NW-W/SE-E formaram estruturas do tipo "dúplex de Riedel".

A Formação Camarinha foi deformada por nova reativaçăo deste megalineamento, estirando seixos do seu fácies conglomerático, com valores de Rs $=1.8-2.0$.

Diversas reativaçóes tiveram lugar durante o Fanerozóico, até movimentos suaves que parecem estar presentes nos dias atuais.

Abstract: Two distinct events (Cubatāo and Lancinha) were recognized to have taken place for the structural installation of the Alem Paraitba-Cubatão-Lancinha lineament.

The Cubatăo strike-slip fault affected gneissic rocks, producing mylonites and blastomylonites, associated with arnphibolite facies metamorphism and essentially ductile deformation along its strike.

The overlying Açungui metasediments were deformed due to reactivation of earlier weakness planes originated at the Cubatäo event. Several secondary structures, such as en échelon folds, synthetic and antithetic faults, Y(D), X and T fractures were simultaneously developed, in accordance with Riedel's Model. Generalized fracturing and rather few brecciation, along with lenticularization and constriction of some beds are associated phenomena. These deformations all were produced at intermediate crustal level and are due to the Lancinha strike-slip event.

Ductile and brittle-ductile transcurrent shears, beside brittle deformations, were exposed where transpressional stresses succeeded to cut across the corc gneisses of the structure known as Nucleo do Betara. NW-W/SE-E oriented stresses also led to Riedel's duplex structures.

Deformation of the Camarinha Formation was caused by a new reactivation of this mega shear zone. Pebble elongation measuremients performed in the conglomeratic facies of this sequence indicated values of $R_{s}=1.8-2.0$.

Several reactivations also took place during Phanerozoic times and gentle movements seen to be notable in present times. 


\section{GARDA, Glanna Maria}

A Alteragāo hidrotermal do contexto da Evoluçāo Geológica do Maciço Alcalino de Poços de Caldas, MG-SP. 14 de março. 227p. 1 vol. Orientador: Horstpeter Herberto Gustavo José Ulbrich.

Resumo: O Maciço Alcalino de Poços de Caldas ocupa $800 \mathrm{Km}^{2}$, sendo que aproximadamente um quarto desta área encontra-se alterada por açäo hidrotermal, proporç̧⿸厃 incomum quando comparada aos demais macif̧os alcalinos conhecidos no mundo.

A alteraçäo hidrotermal está associada as mineralizaçōes de $\mathrm{Zr}$, U e Mo do planalto, predominantemente localizadas na sua porçăo centro-sul, na chamada "estrutura circular centro-leste". Ali, a coloraçấo típica da rocha alterada e do solo, regionalmente denominados de "rocha potássica" é bege esbranquiçado a creme claro.

A mina Osamu Utsumi, também conhecida como a jazida de urânio do Campo do Cercado, situa-se a $25 \mathrm{~km}$ ao sul da cidade de Poços de Caldas e foi explorada, de 1977 até 1989, pelo método da cava a ḉu aberto. A área da mina é um complexo conduto de brechas ("breccia pipe"), mais ou menos irregular, encaixado em fonбlitos e nefelina sienitos, os primeiros predominantes nas porçōes W e N-NE, e os segundos, nas porçóes E e S-SE. Tambem são encontrados pequenos corpos de pseudoleucita fonólitos e diques de biotita lamprofiros.

As brechas que constituem o conduto central são, na realidade, aglomerados polimícticos, de textura sustentada por clastos e matriž, com fragmentos de dimensóes desde decimétricas a métricas. A matriz também e formada por fragmentos de várias dimensões. As brechas marginais (oligomícticas) apresentam textura sustentada por clastos: nas brechas do tipo "eraquellee" a movimentaçăo dos fragmentos é quase nula, enquanto que nas brechas de fragmentaçăo ("shatter breccias") os fragmentos encontram-se afastados entre si, por movimentaçäo e rotaçâo, gerando-se, assim, "poros" (varios) angulosos.

As caracteristicas da mineralizaçăo primária variam com a profundidade; nas áreas mais profundas (zona reduzida), săo encontradas predominantemente na matriz e nos interstícios das brechas zircão, pechblenda, esfalerita, galena e principalmente minerais de Mo, pirita e fluorita. A mineralização secundária formou-se pelo avanço da frente de oxi-reduçăo, sendo que os teores mais elevados de U encontram-se imediatamente abaixo desta. Os bxidos de $\mathrm{U}$ que ai precipitam sảo uraninita e pechblenda.

A alteração hidrotermal 6 responsável pela transformação da nefelina em illita (politipos $1 \mathrm{M}$ e $2 \mathrm{M}$ ) e pela reconstituição textural do feldspato potássico (ortoclásio a microclínio intermediário de alta triclinicidade), que agora apresenta aspecto "pulverulento", com inclusões de 6xidos de Fe, de illita e grande quantidade de inclusóes fluidas. A presença anterior de minerais máficos é inferida pela concentraçáo de minúsculos grăos de minerais opacos, illita, carbonatos, e argilominerais do grupo das esmectitas.

A alteração hidrotermal não oblitera a textura original da rocha, o que permite esboģar um esquema de perdas e ganhos (balaņ̧o geoquímico), através do calculo isovolume. Caracterizam-se perdas reais para $\mathrm{Na}_{2} \mathrm{O}, \mathrm{Fe}_{2} \mathrm{O}_{3}, \mathrm{FeO}, \mathrm{CaO}, \mathrm{MgO}$ e $\mathrm{MnO}$ e ganho principal para $\mathrm{K}_{2} \mathrm{O}$. Um rápido cálculo mostra que a transformaçáo de $1000 \mathrm{~g}$ de rocha fresca em rocha alterada envolve a perda de $31 \mathrm{~g} \mathrm{de} \mathrm{Na}_{2} \mathrm{O}$ e o ganho de $10 \mathrm{~g}$ de $\mathrm{K}_{2} \mathrm{O}$.

Parte-se do pressuposto de que o mecanismo de colocação das rochas alcalinas do Maciço de Poços de Caldas foi semelhante ao modelo de "caldeira ressurgente". As primeiras manifestaçōes magmáticas foram as rochas piroclásticas e os derrames, hoje preservados apenas no Vale do Quartel. Segue-se a intrusẩo subvulcânica, principalmente de egirina fonolitos e fonólitos porfiríticos, com a formação dos anéis topograficos que delimitam boa parte do perímetro do maciço. Nefelina sienitos devem 
ter-se cristalizado a temperatura entre 500 e $800^{\circ} \mathrm{C}$; pseudoleucita fonólitos e fonblitos afíricos constituem corpos menores. Em algum momento da história evolutiva, deve ter havido uma nova intrusão de magma (que gerou a "estrutura circular centro-leste*?) nas rochas já bastante resfriadas $\left(300-400^{\circ} \mathrm{C}\right)$, o que provocou seu brechamento, segundo o modelo de geração de corpos de "porphyry copper". O brechamento facilitou a circulaçăo de fluidos que promoveram a remoção e distribuição de calor.

Dever-se-ia esperar uma seqüência de minerais de alteraçäo adaptada a temperaturas em contínuo decréscimo; entretanto, apenas illita e feldspato alcalino são observados nas porçōes do planalto alteradas por açăo hidrotermal, e sua formaçăo parece ter sido controlada mais fortemente por fatores cinéticos do que térmicos. A circulação irrestrita de fluidos hidrotermais relativamente mais quentes ter-seia dado no início do processo, diminuindo imediatamente apos o resfriamento da área brechada (e do corpo magmático subjacente), levando o sistema a patamares cinéticos que inviabilizariam alteraçōes hidrotermais posteriores. Sucedeu-se a alteração intempérica, que produziu caulinita, gibbsita, oxidaçāo de minerais, etc., e destruiçẩo da textura original da rocha; foi pouco eficiente na geração de novos minerais, mas muito eficiente na redistribuição dos elementos $\mathrm{Zr}$, U c Mo, na transformaçăo de pirita cm óxidos $\mathrm{c}$ hidróxidos c na destruiçâo de fluorita na zona oxidada.

Abstract: The Pogos de Caldas Alkaline Massif covers $800 \mathrm{~km}^{2}$, a quarter of which is hydrothermally altered. Such proportion is uncommon, when compared to the known alkaline massifs of the world.

The hydrothermal alteration is associated with $\mathrm{Zn}, \mathbf{U}$ and $\mathrm{Mo}$ mineralizations which are predominantly located in the central-southern portion of the massif, in the "central-eastern circular structure:. The colour of the altered rock (and its soil) in that area is typically whitish beige to yellowish white and is regionally called "potassic rock".

The Osamu Utsumi Mine, also referred to as the uranium ore of Campo do Cercado, is located $25 \mathrm{~km}$ to the south of Pogos de Caldas City and was explored, from 1977 to 1989, through the open pit method. The mine area is a more or less irregular, complex breccia pipe, enclosed by phonolites and nepheline syenites, the former occupying the $W$ and N-NE and the latter, the $E$ and S-SE portions of the mine. Small bodies of pseudoleucite phonolites and biotite lamprophyres also occur.

The breccias that constitute the central vent are actually polymictic, clast-matrix supported agglomerates, with fragments of decimetric to metric dimensions. The matrix is also formed by fragments of several sizes. The marginal breccias are oligomictic and clast supported: in the "craquelée" type the movement of the fragments was almost inexistent, while in the shatter breccias, the fragments are slightly set apart, showing angular voids.

The characteristies of the primary mineralization vary with depth; in the deepest portions (reduced zone), zircon, pitchblende, spharelite, galena and mainly Mo minerals, pyrite and fluorite are found in the matrix and in the interstices of the breccias.

The secondary mineralization was formed by the advancing movement of the oxidationreduction front. The highest grades are found immediately below such front. The $U$ oxides that precipitate are uraninite and pitchblende.

The hydrothermal alteration is responsible for the transformation of nepheline in illite (1M and $2 \mathrm{M}$ polytypes) and for the textural reconstruction of the potassic feldspar (orthoclase to intermediate microcline of high triclinicity), which now presents a dusty appearance, with oxides, illite and fluid inclusions. The previous existence of mafic minerals is inferred from the concentrations of tiny grains of opaque minerals, illite, carbonates and clay minerals of the smectite group. 
The hydrothermal alteration does not destroy the original texture of the rock. It is possible to draw a gain and loss scheme (geochemical balance) assuming isovolumetric alteration. The real losses are of $\mathrm{Na}_{2} \mathrm{O}, \mathrm{Fe}_{2} \mathrm{O}_{3}, \mathrm{FeO}, \mathrm{CaO}, \mathrm{MgO}$ and $\mathrm{MnO}$, and the main gain is of $\mathrm{K}_{2} \mathrm{O}$. A simple reckoning shows that the transformation of $1,000 \mathrm{~g}$ of fresh rock in altered rock involves the loss of $31 \mathrm{~g}$ of Na $2 \mathrm{O}$ and the gain of $10 \mathrm{~g}$ of $\mathrm{K}_{2} \mathrm{O}$.

It is supposed that the Poços de Caldas Massif emplacement was similar to the Smith \& Bailey's resurgent couldron model. The first magmatic manifestations were the pyroclastic rocks and lava flows, presently only preserved in the Vale do Quartel. A subvolcanic intrusion followed, mainly of aegirine and porphyritic phonolites, forming the topographic rings that almost completely outline the massif's perimeter. Nepheline syenites crystallized at temperatures of $500-800^{\circ} \mathrm{C}$; pseudoleucite phonolites and aphyric phonolites formed smaller bodies. Later in the emplacement history, a new influx of magma occurred (which produced the "central-eastern structure"?) into already cooler rocks $\left(300-400^{\circ} \mathrm{C}\right)$, which caused their brecciation (similar to the model of formation of porphyry copper bodies). Fluids could easily circulate, removing and redistributing heat.

A sequence of alteration minerals adapted to lowering temperatures should be expected; however, only illite and alkaline feldspar are observed in the hydrothermally altered portions of the massif, and their formation must have been controlled mainly by kinetic, other than thermal factors. The irrestrictive circulation of relatively hotter hydrothermal fluids must have happened at the beginning of the process, diminishing immediately after the cooling of the brecciated areas (and the subjacent magmatic body), leading the system to kinetic levels that made subsequent hydrothermal alteration impossible. Then, weathering followed, producing kaolinite, gibbsite, oxidation of opaque minerals, etc., and destroying the original texture of the rock; it was inefficient in the production of new minerals, but very efficient in the redistribution of elements such as $\mathrm{Zr}, \mathrm{U}$ and $\mathrm{Mo}$, the transformation of pyrite in oxides and hydroxides and destruction of fluorite in the oxidated zone.

\section{HIPPERTT, Joảo Fernando Martins}

Contribuiçāo à geologia e petrologia dos "Augen"-Gnaisses de Niterói, RJ. 26 de abril. 203p. 1 vol. Orientador: José Vicente Valarelli.

Resumo: Uma área de aproximadamente $80 \mathrm{~km}^{2}$, representativa dos terrenos do "augen"-gnaisses da margem ocidental da Baía de Guanabara (regiảo de Niterói) foi mapeada em escala 1:50.000. Individualizaram-se três grandes unidades do mapeamento: uma unidade principal do gnaisses graniticos ("augen"-gnaisses e leptinitos) na porção central da área, que transiciona para a unidade de gnaisses granodioríticos a NW, o para e granodiorito porfiroblástico a SE.

Um estudo sistemático das feições de deformaçāo dúctil em quartzo e feldspatos (extinçâo ondulante, bordas de recuperação, recristalização, reduçōes de granulometria, orientaçăo preferencial cristalográfica) possibilitou uma classificação microtextural destas rochas, onde ficou estabelecida uma transição desde granitoides a gnaisses não-miloníticos, passando por faixas de blastomilonitos graniticos e granodioríticos, até milonito gnaisses e milonitos típicos na porçấo interior mais estressada da estrutura aqui denominada da Zona de Cisalhamento Dúctil de Niterói - ZCDN: uma faixa de rochas miloníticas com 10 km de largura na área de estudo, com foliação milonitica vertical N70E e lineaçăo mineral horizontal.

Os megacristais de K-feldspato (microclínio pertitas e mesopertitas, Ab>20\% e An>6\%) foram petrograficamente caracterizados como porfiroblastos, sendo em geral anteriores ou contemporâneos 
à deformaçâo dúctil principal. Propõe-se que tenham se desenvolvido por substituição metassomática ou uma matriz quartzo-plagioclásica original. Análises difratométricas em diferentes variedades tipológicas dos megacristais identificaram sempre a simetria triclínica em diferentes graus de obliquidade (microclínios intermediários e máximos).

As mirmequitas que ocorrem circundando os megacristais do $\mathbf{K}$-feldspato foram tema de um detalhado levantamento microtextural, sendo interpretadas segundo um novo modelo infiltrativo - aqui proposto - que vineula sua origem a fase final do evento de metassomatismo potássico.

"Augen"-charnockitos ocorrem como manchas difusas de dimensôes variáveis na porção estressada da ZCDN. A observação petrográfica de reaçócs metamórficas de entrada no fácies granulito e a identidade quimica com os "augen"-gnaisses de fácies anfibolito permitiram atribuir a estas rochas uma origem por metamorfismo progradante, favorecido provavelmente pelo aporte carbônico no interior mais deformado da ZCDN.

Abstract: In an area of $80 \mathrm{~km}^{2}$, three major units has been mapped at a 1:50.000 scale in the augen gneisses terrain of the western margin of the Guanabara Bay. The main unit comprises granitic gneisses (augen gneisses and leptinites) which pass laterally to the granodioritic gneisses unit, to the northwest, and to the porphyroblastic granodioritc unit, to the southeast.

A petrographic study was carried out on the ductile deformation features in quartz and feldspars (undulatory extinction, recovery-recrystallization edges, grain size decrease, preferential crystallographic orientation), resulting in a microtextural classification of all granitic ("sensu lato") rocks. A complete transition has been identified from nonmylonitic gneisses and granitoids, passing into granodioritic and granitic blastomylonites, to typical mylonites in the most stressed bolt of the structure, heroin named, the Niter6i Ductile Shear Zone. It is a high grade shear zone, $10 \mathrm{~km}$ wide, with N70W vertical mylonitic foliation and horizontal mineral lincation.

The K-feldspar megacrystals (ternary mierocline perthites and mesoperthites with $\mathrm{Ab}>20 \%$ and $A n>6 \%$ ) can be interpreted as porphyroblasts which have formed prior to, or during, a ductile deformation event. Potassium metassomatism have been inferred to explain their origin. Diffractometric analysis in several types of megacrystals have always shown a tryclinic symmetry with different obliquities (intermediate and maximum microcline).

Myrmekites have been microtexturally analysed in detail and explained according to a new infiltrative model, herein proposed, which relates their origin to the end of K-metasomatic event.

Augen charnockites oceur as diffuse spots with variable dimensions in the most stressed domains. The observation of metamorphic reactions indicating the beginning of the granulite facies, and the chemical identity of charnockites with the augen gneisses of the amphibolite facies, allows to establish a prograde metamorphic origin, probably started by $\mathrm{CO}_{2}$ flux in the shear zone.

\section{HIRATA, Ricardo César Aokd}

Amostradores de Vapores do Solo (AVS): desenvolvimento de uma técnica para a detecçâo de águas subterráneas contaminadas por solventes organicos voláteis. Estudo de caso de Porto Feliz, São Paulo. 24 de outubro. 133p. 1 vol. Orientador: Robert William Cleary.

Resumo: A Amostragem de Vapores do Solo (AVS) é uma técnica introduzida recentemente e usada para deteç̧ão de forma indireta, da contaminação das águas subterrâneas por solventes orgânico-volátcis, 
incluindo entre estes, os chamados DNAPL. O rápido desenvolvimento desta técnica foi motivado pela dificuldade e elevados custos que estão envolvidos os métodos tradicionais na avaliação do impacto de um acidente com substâncias organo-sintéticas. Tais métodos implicam na perfuraçăo de numerosos poços de monitoraçäo associados a um programa de coleta de água $e$ análise.

Dadas as caracteristicas destes produtos químicos de não apresentarem contrastes elétricos e possuírem baixa solubilidade $\mathrm{em}$ água, métodos geofísicos comumente usados (eletrorresistividade e eletromagnéticos) não têm se mostrado eficazes.

A técnica AVS envolve a extração de uma pequena quantidade de gases succionado do solo a pouca profundidade e sua análise em campo ou laboratório, identificando os compostos presentes e correlacionando as composiçōes dos vapores e das águas subterrâneas. O princípio de deteç̧âo relaciona-se com o estabelecimento de um gradiente de concentraçăo química na zona năo saturada, resultando um fluxo difusivo ascendente do contaminante nas áreas onde as águas subterrâneas se acham poluídas.

O presente trabalho desenvolve a técnica AVS inovando na forma de aprisionamento de vapores, quando se sugere o uso de colunas adsorventes duplas de carvão ativado, e adapta procedimentos de laboratório, com uso de cromatografia gasosa, para análise de colunas e identificaçăo dos poluentes.

Esta dissertaçäo apresenta os resultados do uso da técnica AVS desenvolvida neste estudo, quando da aplicą̧ão pioneira no Brasil, acidente ambiental ocorrido em Porto Feliz (SP), onde o vazamento de um tanque de solventes orgânicos causou a contaminaçấo de expressiva porção do aquúfero.

O AVS permitiu avaliar com sucesso a extensão do acidente de poluição no aquífero e $\mathrm{cm}$ subsuperficie e o formato da pluma contaminante. O mapeamento com AVS definiu trés zonas com diferentes concentrações de vapores: altas, médias e baixas e mostrou que a pluma está se deslocando no sentido SE para NW atingindo, no momento, uma área de $113.000 \mathrm{~m}^{2}$. A coleta de vapores do solo a diferentes profundidades possibilitou o estabelecimento das taxas de volatilizaçâo, quantificando o fluxo vertical de tetracloreto de carbono em $1,0 \times 10^{-5} \pm 6,9 \times 10^{-7} \mu \mathrm{g} / \mathrm{m}^{2} / \mathrm{s}$ e clorofórmio em $6,4 \times 10^{-5} \pm 1,7 \times 10^{-5} \mu \mathrm{g} /$ $\mathrm{m}^{2} / \mathrm{s}$. Os resultados das amostras de água subterrânea e vapores do solo permitiram estabelecer correlações bastante expressivas de 0,9 e 0,8 para cloroformio e tetracloreto de carbono. Com o intuito de medir o tempo de trânsito e volatilizaçáo dos compostos halogenados de interesse $\mathrm{cm}$ meio não saturado, foram preparados experimentos envolvendo colunas de areia em laboratório. Os testes permitiram avaliar as perdas por volatilização do cloroformio e tetracloreto de carbono numa razão de 20 e $30 \%$, após 30 horas de experimento. Esta dissertaçảo analisa também, de forma crítica, trabalhos publicados por outros pesquisadores, permitindo avaliar a técnica aqui proposta comparativamente a outras.

A pesquisa em quase 100 documentos possibilitou estabelecer alcances c restrições do método, dando ênfase na influência do meio e dos compostos no sucesso do uso do AVS, tema ainda pouco explorado por pesquisadores desta técnica. Este estudo sugere ainda uma classificaçăo em 6 grupos do método AVS, segundo sua configuraçâo e forma de aprisionamento e análise dos contaminantes.

Abstract: Soil-gas sampling is a recently introduced technique for the indirect detection of groundwater contamination by volatile organies, including dense non-aqueous phase liquids (DNAPLs), such as those involved in the Porto Feliz accident. The rapid development of this technique was prompted by the difficulties and high costs that are involved in the evaluation of the impact of an accident with synthetic organic substances using traditional methods. The traditional approach involves the drilling of many monitoring wells to be used subsequently in a groundwater sampling and laboratory analysis program. In the Porto Feliz case, the chemical compounds involved showed negligible electrical contrast and low solubility in water, making commonly used geophysical methods, such as electrical resistivity and 
electromagnetic induction logging, inapplicable.

The soil gas sampling technique involves the extraction of a small amount of soil gas from a shallow depth with subsequent analysis in the field or laboratory, identifying the compounds present and correlating and the vapor composition with the composition of the underlying groundwater. The principle behind the technique is related to the establishment of a chemical concentration gradient in the unsaturated zone which causes an upward diffusive flux of contaminants in areas where the underlying groundwater is contaminated with volatile organics.

The present research developed a soil gas sampling technique which is innovative in both the manner gases are captured, through the use of a double activated carbon column apparatus, and in the laboratory procedures used to analyze the columns, and identify the pollutants with gas chromatography. The dissertation presents the results of the application of the soil gas sampling technique developed in this study to the environmental accident which occurred in Porto Feliz when a large solvent tank leaked and contaminated a significant portion of the underlying aquifer. It is the first application of the soil gas sampling technique in Brazil. The technique allowed the successful evaluation of the extent of aquifer contamination and the shape of the groundwater plume. Plume mapping using soil gas concentrations defined three zones with different vapor concentration levels: high, medium and low. It also showed the plume moving in a SE to NW direction, contaminating $113,000 \mathrm{~m}^{2}$ at the present time.

The extraction of vapors at different depths allowed the calculation of soil gas emission flux rates of $1,0 \times 10^{-5} \pm 6,9 \times 10^{-7}$ and $6,4 \times 10^{-5} \pm 1,7 \times 10^{-5} \mu \mathrm{g} / \mathrm{m}^{2} / \mathrm{s}$ for chloroform and carbon tetrachloride respectively. The results of groundwater and vapor sampling showed excellent correlation coefficients of 0,9 and 0,8 for chloroform and carbon tetrachloride respectively.

With the idea of measuring the travel time and volatilization of halogenated organies of interest in the unsaturated zone, experiments involving sand columns were prepared in the laboratory. The tests allowed the evaluation losses of chloroform and carbon tetrachloride on the order of 20 and $30 \%$ respectively after 30 hours of flow.

The dissertation constructively analyzes studies published by other researchers, allowing a comparative evaluation of their techniques with the technique developed in this study. A review of more than 100 published documents on the subject allowed the establishment of restrictive limits on the method, highlighting the influence of the medium and the physico-chemical properties of the chemical compounds on the chemical compounds on the success of the soil gas sampling technique. The literature review also resulted in classifying soil gas sampling into 6 groups according to the physical method used, the manner of gas capturing and the method of analyzing the gases.

\section{MARTINS NETO, Rafael Gióia}

Sistemática dos Ensifera Insecta (Orthopteróida) da Formação Santana (Cretáceo Inferior do Nordeste do Brasil). 16 de agosto. 264p. 1 vol. Orientador: Oscar Rösler.

Resumo: A pesquisa aborda o estudo taxonômico de 508 espécimes de insetos fósseis da Ordem Ensifera (grilos e esperanças), provenientes do nivel de calcário laminado, parte superior do Membro Crato, unidade inferior da Formação Santana (Cretáceo Inferior), Bacia do Araripe, de afloramentos situados nas proximidades dos munićpios de Santana do Cariri e Nova Olinda (Ceará, Nordeste do Brasil). O estado de preservaçăo é excelente, espécimes relativamente completos, em sua maioria articulados e a fossilização se processou através da substituição da quitina pela apatita. Outros exemplares estão 
representados por impresső́es. O tema é inédito, de natureza básica.

A primeira parte deste trabalho atém-se ao contexto geográfico, temporal e geológico regional, fornecendo-se breve levantamento das diversas propostas de divisōes estratigráficas que envolvam sedimentos da Bacia do Araripe, baseando-se em dados disponíveis na literatura. Especial ênfase é dada ao conteádo paleontologico da Formaçäo Santana, listando-se todos os taxa conhecidos, dos diversos grupos de organismos ali representados. São abordados também, de maneira breve, embora abrangente, a idade e a ecologia dessa importante unidade estratigráfica.

A segunda parte dedica-se ao embasamento teórico, envolvendo classificação, morfologia, metodologias diversas, problemas taxonômicos (dimorfismo sexual) e levantamento de todo o registro fóssil de Ensifera meso-cenozoicos, para efeito de comparaçáo, segundo a literatura disponivel. A seguir dá-se ênfase à descrição dos 27 taxa identificados que representam 26 novas espécies (distribuidas em 12 gêneros) de 6 familias (4 das quais com representaçáo atual).

A terceira parte refere-se aos resultados e conclusōes obtidos, abordando-se aspectos bioestratigraficos, paleoambientais, baseando-se nos texa descritos na Parte 2. Procura-se demonstrar que a fauna de Ensifera do Membro Crato é resultante de possível especiação alocrônica, decorrente de alteraçōes climáticas e crise biótica. A discussão envolve teorias de especiação, além de consideraçōes sobre ciclode vida Ensifera. Implicaçōes cronoestratigráficas c climáticas sâo sugeridas, bem como $€$ efetuada análise tafonômica e discussôes sobre a provável origem da fauna, considerada excepeional.

Abstract: This dissertation presents the results of a taxonomic study of 508 specimens of fossil insects of the order Ensifera. All of the material comes from laminated limestone of the upper most part of the Crato Member, lowest unit of the Santana Formation (Lower Cretaceous), Araripe Basin, near Santana do Cariri and Nova Olinda municipalities (Ceará State, Northeast Brazil). The fossils are very well-preserved, articulated specimens. The fossilization process evolved the substitution of carbonate and chitinous matter by apatite.

The first part of this work deals with the geographic, temporal and regional geology context and furnishes an account of the various stratigraphic schemes proposed for the Araripe Basin sedimentary sequences. Special reference is made to the paleontological record of the Santana Formation, listing all known taxa in this stratigraphic unit.

The second part contains the theoretical basis for the classification and methodology here employed, including a discussion of taxonomic problem and the Mesozoic-Cenozoic ensiferan fossil record. Following this 27 taxa are described which represent 26 new species distributed among 12 genera of 6 families ( 4 of which are extant).

Finally, the third part presents the results and conclusions of this rescarch focussing especially upon biostratigraphical and paleoenvironmental aspects based on the taxa described in Part 2 . It is demonstrable that the Ensifera fauna from the Crato Member resulted from possible allochronic speciation in concert with climatic changes and biotic crises. This discussion involves speciation theories and considerations on the life-cycle of this group. Chronostratigraphic implications based on the apparent lifecycle of these insects, taphonomic analysis and origins of this exceptional fauna are also discussed.

\section{MELO, Mario Sergio de}

A Formaçäo Pariquera-Açu e depósitos relacionados: sedimentação, tectônica e geomorfogênese. 13 de junho. 211p. 1 vol. Orientador: Armando Marcio Coimbra. 
Resumo: O objetivo dos estudos realizados foi a determinação das correlaçốes entre sedimentaçâo, tectônica, paleoclimas c feiçōes morfológicas (níveis de terraços) na área de afloramento da Formação Pariquiera-Açu, cobertura sedimentar continental cenozóica no baixo vale do Rio Ribeira do Iguape, no litoral sul do Estado de São Paulo.

Com base nas características litologicas e relaçöes estratigráficas observadas, os depósitos cenozbicos anteriormente atribufdos a Formaçâo Pariqūera-Açu foram separados em cinco unidades principais distintas: Formaçăo Sete Barras (definida durante a realização do presente estudo); Formação Pariqûera-Açu (para a qual apresenta-se proposta de redefiniçâo no presente estudo), compreendendo uma fácies fanglomerática de leques aluviais coalescentes, uma fácies de planície fluvial meandrante, e uma fácies lacustre; depósitos de cascalhos em nivel superior de terraços (situados em posiçāo topográfica mais elevada); depósitos de cascalhos em nível intermediário de terraços (rebaixados em relação aos anteriores); e depósitos colívio-aluviais.

A Formaçăo Sete Barras é constituida de depósitos rudáceos de leques aluviais aparentemente gradando para depósitos finos, lacustres, formados provavelmente no Paléggeno, sob condiçóes de clima seco. Preenche o Gráben de Sete Barras, uma depressão tectônica de direção N50E, formada na interseção da Zona de Cisalhamento de Cubatåo (pré-cambriana a cambro-ordoviciana) com o Alinhamento de Guapiara (mesozb́ico), durante fase de esforços trativos na direçăo WNW-ESE, contemporâneos da sedimentaçăo.

A reativação de falhas WNW-ESE paralelas ao Alinhamento de Guapira no Nébgeno, sob ação de esforços trativos reorientados na direçáo E-W, acarretou basculamentos de blocos c barramentos de paleodrenagem, ensejando a acumulaçäo da Formaçáo Pariquêera-Açu, sob condiçōes de clima úmido, e com o nível relativo do mar abaixo do atual. Junto às falhas desenvolveu-se sistema de leques aluviais coalescentes, gradando lateralmente para planicie fluvial meandrante e lago.

Durante o final do Neógeno e o Pleistoceno a região foi submetida a soerguimento diferencial, com entalhamento progressivo da drenagem, mais pronunciado no bloco relativamente mais elevado, a SW do Alinhamento de Guapiara. Fases de clima seco possivelmente conjugadas com fases de quiescência tectônica ensejaram entăo a elaboraçáo de dois nf́veis escalonados de terraços com cascalhos, estes depositados $\mathrm{cm}$ sistema fluvial entrelaçado.

Formaram-se ainda na área depósitos colúvio-aluviais no final do Négeno e no Pleistoceno, quando o paleo-relevo já era muito semelhante ao atual. Estes depósitos aparentemente refletem remobilizaçốes maciças do regolito durante oscilaçốes climáticas, e apresentam-se truncados por falhas, indicando tectônica sin e pós-sedimentar. Esta última é testemunhada principalmente por falhas inversas e com rejeito direcional cortando os depositos colúvio-aluviais, que indicam fase de esforços compressivos de direçáo NE-SW, ativos provavelmente no Pleistoceno Inferior.

Diferenças nas cotas dos aluvióes em baixos terraços nos dois blocos separados pelo Alinhamento de Guapiara sugerem que discreta tectônica residual possa estar determinando soerguimento diferenciado dos blocos até os tempos geológicos mais recentes.

Abstract: Cenozoic deposits previously attributed to the Pariquiera-Açu Formation (a continental sedimentary cover of the low Ribeira do Iguape River valley, southern São Paulo State, Brazil) can be separated in five different units: Sete Barras Formation (proposed in this study); Pariquiera-Açu Formation (reviewed in this study); two topographic levels of gravels in fluvial terraces; and colluvial-alluvial deposits.

Sete Barras Formation is constituted of coarse fanglomeratic deposits probably grading to clayey lacustrine layers. They were formed probably in the Palaeogene, under dry climate. This 
sedimentary unit fills the Sete Barras Graben, an elongated tectonic depression trending N50E, just in the intersection of the ENE-WSW Cubatăo Shearing Zone (Proterozoic to Cambrian-Ordovician) and the WNW-ESE Guapiara Alignment (Mesozoic). Tractive stresses trending WNW-ESE synchronous to the sedimentation have originated the graben trough.

Reoriented tractive stresses trending E-W which were active during the Neogene reactivated WNW-ESE faults parallel to the Guapiara Alignment. This caused block tilting and drainage damming, and accumulation of the Pariqüera-Açu Formation, under humid climate and lower sea level. Three facies can be recognized in this formation: fanglomeratic, fluvial meandering and lacustrine.

Differential uplift during the end of the Neogene and the Pleistocene raised the SW block of the Guapiara Alignment. Two main levels of fluvial terraces with gravels and sands of braided system were then developed on this raised block, during dry climate phases and conditions of sea level stability.

Colluvial-alluvial deposits younger than the terraces were formed when paleorelief was very similar to present-day relief. These deposits are related to the Quaternary climatic changes. They are cut by inverse and strike-slip faults which indicate compressive stresses trending NE-SW, active probably during Lower Pleistocene.

Geomorphological characteristics of modern alluvial plains indicate also some possible tectonic activity along the Guapiara Alignment during recent geological times.

\section{NOGUEIRA, Sonia Aparecida Abissi}

Estudo das mineralizaçōes filloneanas aurifferas do deposito de Piririca, Vale do Ribeira, SP. 03 de dezembro. 91p. 1 vol. Orientador: Aledir Paganelli Barbour.

Resumo: As mineralizaçōes filoneanas auriferas da regiầo do Piririca, Vale do Ribeira, de características epigenéticas, parecem estar relacionadas a uma zona de cisalhamento dúctil-rúptil, limitada pelos lineamentos Agudos Grandes e Ribeira, de expressáo regional.

Estratigraficamente a região faz parte de uma seqưencia de rochas metavulcanosedimentares, com metabásicas associadas, de baixo grau metamórfico, pertencente à Formação Perau.

Os veios mineralizados mais significativos estão associados às rochas metabśsicas, que se intercalam de forma concordante nos metassedimentos finos, e são constituídas essencialmente por anfibólios da série tremolita-actinolita, plagioclásio sódico, epídoto zoisita e clorita, associação típica de baixo grau de metamorfismo.

Estudos petrográficos c petroquímicos sugerem para essas rochas básicas, uma natureza intrusiva, possivelmente sub-vulcânica, com composição original em um gabro ou diabásio. Indicam ainda, que sofreram variaçóes composicionais, associadas provavelmente a processos nâo isoquímicos de adição de $\mathrm{K}$, Na e Ca, provocados por fenômeno de alteraçāo hidrotermal.

O ouro aparece quase sempre, preenchendo fraturas e cavidades de pirita e arsenopirita de granulaçáo grossa, que representam os minerais mais abundantes entre os sulfetos estudados. Em quantidades subordinadas observam-se: calcopirita, boulangerita, bournonita, jamesonita, grupo do fahlore, blenda, galena, bornita, e ilmenita. Quartzo leitoso branco constitui o mineral de ganga dominante.

A tentativa de estabelecimento de uma paragênese temporal entre os minerais acima considerados, coloca pirita e arsenopirita de granulação grossa e ilmenita como anteriores a uma fase de brechação/milonitização, após a qual seguiram os outros minerais relacionados, geralmente preenchendo vênulas e fraturas nos dois sulfetos principais. 
O estudo de inclusōes fluidas no quartzo leitoso branco mostrou a presença de inclusōes primárias do tipo carbônicas, aquo-carbônicas e eminentemente aquosas que permitiram sugerir fluidos mineralizantes aquosos, ricos em $\mathrm{CO}_{2}\left(>25\right.$ moles $\% \mathrm{CO}_{2}$ ), de baixa salinidade ( $<11$ eq $\%$ peso $\mathrm{NaCl}$ ), com temperaturas de deposiçăo de moderadas a altas $\left(200-400^{\circ} \mathrm{C}\right)$.

Análises da composiçâo isotópicas de $\mathrm{Pb}$ de galenas dos veios sulfetados estudados, indicam para as soluçóes mineralizantes uma origem crustal a partir de processos de remobilização das rochas encaixantes, associados a eventos metamórficos regionais de idade entre 1,4 e 1,1 b.a., a exemplo do que acontece com galenas de depósitos plumbo-argentiferos do Vale do Ribeira.

A integração dos resultados obtidos nos estudos realizados e a comparaçăo com trabalhos em depósitos de ouro de outras partes do mundo, sugerem um modelo metamórfico para a derivaçâo dos fluidos mineralizantes, entendendo-se que possam ver originados a partir de processos de devolatilização dos terrenos metamórficos de baixo grau, capazes de produzir fluidos carbônicos e aquo-carbônicos de baika salinidade, com zonas de cisalhamento representando elementos fundamentais para a efetivação dos processos de lixiviação, transporte, canalização e interaçăo fluido-rocha encaixante.

Abstract: The gold-bearing vein from the Piririca, region, Ribeira Valley, State of São Paulo, Brazil, show epigenetic features and seem to be mainly related to a ductile-brittle shear zone, which is subordinated to the Agudos Grandes and Ribeira tectonic lineaments, of regional expression.

From a stratigraphic point of view the area belongs to a sequence of metavolcanic sedimentary rocks with associated metabasic rocks, which are characterized by a low degree of metamorphism. These rocks are correlated to the Perau Formation.

The most significant mineralized veins are associated to metabasic rocks, concomitantly intercalated to fine metasediments. They are mainly constituted by amphibole of the tremolite-actinolite series, sodium plagioclase, epidote-zoizite and chlorite, a typical association of low grade metamorphism.

Petrographic and chemical analyses suggest for these basic rocks an intrusive, possibly subvolcanic origin, with an initial composition of a gabbro or a diabase. Furthermore the studies indicate variations in the mineralogical composition. They are probably associated to non isochemical addition processes of $\mathrm{K}, \mathrm{Na}$ and $\mathrm{Ca}$ as a result hydrothermal alteration.

Gold is almost always present, filling fractures and cavities of coarse grained pyrite and arsenopyrite, which are the main components of the mineralization. In subordinated quantities the following minerals have been detected: chalcopyrite, boulagerite, bournonite, jamesonite, fahlore group, sphalerite, bornite and ilmenite. Milky quartz represents the dominant gangue.

The paragenetic sequenco here proposed might be considered as a preliminary attempt. In this way coarse grained pyrite, arsenopyrite and ilmenite are considered as an early main phase of sulphide deposition, whose assemblage have been affected by a brecciation mylonitization deformation cpisode. The post-deformation mineral assemblage, already referred, occurs as filling materials of veinlets and fractures which cut across pyrite and arsenopyrite crystals.

Fluid inclusions data of the milky quartz have indicated primary $\mathrm{CO}_{2}$ and $\mathrm{H}_{2} \mathrm{O}-\mathrm{CO}_{2}$ inclusions, which suggest aqueous mineralizing fluids, rich in $\mathrm{CO}_{2}\left(>25\right.$ mole $\left.\% \mathrm{CO}_{2}\right)$ of low salinity $(<11$ wt\% $\mathrm{NaCl}$ equiv.) and with deposition temperatures ranging between 200 and $400^{\circ} \mathrm{C}$.

The $\mathrm{Pb}$ isotopic analyses carried out on the sulphide vein galenas indicate a crustal origin for the mineralizing solutions and the $\mathrm{Pb}$ might be derived of metasedimentary and basement rocks. Similarly to the lead-silver deposits from the Ribeira Valley, the ores might be cmplaced during regional metamorphism, between 1.4 and $1.1 \mathrm{Ga}$. 
The integration of the results obtained during this research and the comparison with similar research which have been done on other gold deposits, suggest a metamorphic model for the origin of the mineralizing fluids. These fluids might be derived from devolatilization processes of low metamorphic terrains, and would be able to produce $\mathrm{CO}_{2}$ and $\mathrm{H}_{2} \mathrm{O}-\mathrm{CO}_{2}$ fluids with low salinity, and shear zones as fundamental elements through which processes of leaching transport and fluid/wall-rock interaction would act.

\section{PELOGGIA, Alex Ubiratan Goossens}

A Faüra Alto Rio Grande na Regiāo de Amparo, SP. 18 de dezembro. 130p. 1 vol. Orientador: Miguel Angelo Stipp Basei.

Resumo: Os terrenos da Faixa Alto Rio Grande na Regiảo de Amparo, SP, apresentam duas associą̧ōes geológicas principais:

a. Rochas ortognáissico-migmatíticas (Complexo Amparo, de idade Arqueana/Proterozfica Inferior), com intercalaçōes de anfibolitos e que englobam uma Associaçáo Máfico-Ultramáfica (Arcadas).

Os anfibolitos associados aos ortognaisses são rochas meta-ígneas de afinidade tolética enriquecidas em elementos lit6filos de fon grande, correspondendo provavelmente a rochas sub-vuleânicas colocadas na forma de diques nos terrenos ortognáissicos, associando-se talvez a uma fase tectônica distensiva.

A Associaçāo Máfico-Ultramáfica de Arcadas constitui um corpo internamente estratificado no qual distinguem-se uma porçâo orto-derivada (xistos ultramáficos e anfibolitos homogêneos), composta por rochas meta-igneas magnesianas de características geoquímicas komatíticas, e uma porçāo paraderivada ou híbrida (anfibolitos bandados), constitufda por prováveis misturas de sedimentos carbonáticos e peliticas e/ou tufáceos, e ainda tendo intercalaçấo de lentes de rochas metassedimentares.

b. Rochas supracrustais (Proterozóico Médio), constituindo um conjunto xisto-quartzítico (Xistos Fazenda Bela Vista e Quartzitos Serra dos Feixos), proximal ao paleo-continente, que corresponde lateralmente a um conjunto gnáissico-calciossilicático (Gnaisses Ribeirão do Pantaleão e Duas Pontes); associa-se um magmatismo ácido pré-orogênico (o corpo granítico tabular da "Unidade dos Gnaisses Graníticos").

Os Xistos Fazenda Bela Vista incluem aproximadamente $400 \mathrm{~m}$ de sillimanita-mica xistos e quartzo-xistos, com intercalaçôes de quartzitos, rochas cálcio-silicáticas, biotita-gnaisses e anfibólio-gnaisses bandados, em contato com a Associação de Arcadas e Orto-gnaisses do Complexo Amparo a Sudeste e Sul.

Os Quartzitos Serra dos Feixos incluem aproximadamente $300 \mathrm{~m}$ de quartzitos maciços ou placosos, micáceos e localmente arcoseanos, com intercalaçôes de níveis de mica-quartzo xistos c metassedimentos bandados.

Os Gnaisses Ribeirão do Pantaleão mostram como tipo característico os granada-biotitaplagioclásio gnaisses cinzentos, com intercalaçōes de quartzitos, mica-xistos, gnaisses quartzosos, quartzitos impuros, sequências bandadas, quartzitos manganesfferos e ferruginosos e anfibolitos. Quimicamente parecem tratar-se predominantemente de grauvacas, derivadas de rochas cálcio-alcalinas intermediárias.

Os Gnaisses Duas Pontes são rochas cálcio-silicáticas bandadas (meta-margas), a clinopiroxênio, K-feldspato, plagioclásio, quartzo e hornblenda predominantes. A espessura chega a $250 \mathrm{~m}$.

Os Gnaisses Graníticos são ortognaisses a biotita, hornblenda e magnetita, constituindo um corpo tabular de 350 a $500 \mathrm{~m}$ de espessura, com intercalaçōes (enclaves?) de xistos ultramáficos e anfibolitos. 
As unidades são englobadas em nappes de dobramento com vergência para NW, desenvolvidas na fase deformacional D2 (que se superimpōe à fase D1, responsável por transporte tectônico das supracrustais sobre os ortognaisses) sob condiçōes metamórficas de médio grau e pressōes intermediárias; tais estruturas são redobradas ainda durante o transporte para NW em condiçóes metamórficas mais brandas (fase D3), e tardiamente cm condiçốes pós-metamórficas. Nāo ocorrem granitos pós-tectônicos.

Abstract: The Alto Rio Grande Belt in Amparo region (State of Sáo Paulo, Brazil) comprises two main geologic associations:

- Migmatitic-orthogneissic rocks (Archean/Early Proterozoic), which encloses amphibolite intercalations (metatholeiitic basic igneous rocks) and a Mafic-Ultramafic Association (a probable volcano-sedimentary sequence with komatiitic geochemical character and uncertain stratigraphic position).

- Supracrustal rocks (Middle Proterozoic), made up of a schist-quartzite group (Fazenda Bela Vista Schists and Serra dos Feixos Quartrites), representing a deposition proximal to a paleo-continental margin, grading laterally to a gneissic-cale-silicatic distal group (Ribeirāo do Pantaleăo Gneisses and Duas Pontes Calcsilicatic rocks), deposited in a deeper portion of the basin.

A pre-tectonic acid magmatism is represented by a metamorphosed magnetite and hornblende-bearing granitic sill.

These supracrustal units occur as folded nappes with northwestward tectonic transport, which were developed during the D2 deformational phase (the D1 phase is associated with a tectonic dislocation of the Supracrustal Sequence over the migmatites). The metamorphic conditions of these deformational phases were of medium grade under intermedite pressure. Refolding of the structures occurred, under weaker metamorphic conditions, still with northwestward tectonic transport and later yet under post-metamorphic conditions.

\section{PIRES, Fernando Alves}

Análise paleoambiental e estratigráfica de seqüências metassedimentares (Grupo Açungui) na regiāo de Iporanga e Apiat-SP. 21 de junho. $168 \mathrm{p} .1$ vol. Orientador: Gilberto Amaral.

Resumo: A pesquisa desenvolvida estudou os indicadores paleoambientais e as relaçóes estratigráficas das sequências deposicionais Betari e Furnas-Lajeado (PIRES, 1988), do Grupo Açungui (Proterozóico Inferior a Médio). Apresenta uma concepçăo dos ambientes de sedimentação através da interpretação dos processos sedimentares, análise de fácies, análise seqüencial c reconhecimento da estratigrafia através de conceitos genéticos e temporais.

A seqũência Betari 6 retrogradacional, associada a cpsódio transgressivo, e representada por sistemas turbiditicos do tipo II e III (MUTTI \& NORMARK, 1987).

A sequêtncia Furnas-Lajeado é progradacional e corresponde a um episódio regressivo. Compreende uma plataforma rasa sob o domínio de ondas que transiciona para o talude e áreas associadas (rampa carbonatica).

A análise estrutural desenvolvida, acompanhada de mapeamento de detalhe, permitiu reconhecer 6 fases de dobramentos na área.

A sequêtncia Betari encontra-se na base, sobreposta pelos metassedimentos carbonáticos da seqüência Furnas-Lajeado. Ambas constituem um ciclo transgressivo-regressivo, com aproximadamente 


\title{
2.000 metros de espessura.
}

\begin{abstract}
Study of paleoenvironmental indicators and stratigraphic relationschips of the Betari and Furnas-Lajeado metasedimentary depositional sequences of the Açungui Group (Lower to Middle Proterozoic, Ribeira river valley, southern Sāo Paulo, Brazil) has led both to the recognition of the sedimentary processes involved, facies analysis and sequence analysis and to the stablishment of a general stratigraphic setting on the basis of genetic and temporal concepts. The Betari sequence represented by type II and III turbiditic systems of Mutti and Normark, is retrogradational in character and associated with a transgressive episode. The Furnas-Lajeado sequence is progradational and related to a regressive episode, represented by wave-influenced, shallow platform to slope (carbonate ramp) sediments. Together these two sequences comprise a transgressive-regressive cycle, with the Betari sequence of the base and the FurnasLajeado sequence at the top, nearly 2,000 metres in thickeness.
\end{abstract}

Structural analysis and detailed mapping have revealed 6 phases of folding in area.

\section{RAHAL, Fábio Gomide}

Produçāo de termofosfato potássico fundido com fosfato de Irecê, BA. 15 de março. 84p. 1 vol. Orientador: José Vicente Valarelli.

Resumo: Termofosfato potássico fundido foi produzido em escala de laboratorio com o emprego de rocha fosfática de Irece (BA), juntamente com o sienito de Triunfo (PE) e a magnesita de Brumado (BA). Resultados de solubilização de fósforo e potássio em solução de ácido cítrico (2\%) acima de $90 \%$ foram verificados para os experimentos com teores de $\mathrm{P}_{2} \mathrm{O}_{5}$ e $\mathrm{K}_{2} \mathrm{O}$ entre 14 e $17 \%$ e 4 e 5\%, respectivamente. As propriedades do termofosfato potássico fundido (cristalizaçăo de apatita, solubilização em ácido cítrico) são controladas pela estruturaçáo do vidro formado, a qual $\varepsilon$ definida pelos clementos formadores de rede, P, $\mathrm{Si}, \mathrm{Al}$ e Fe. A estes elementos estấo associados fenômenos de imiscibilidade líquida, que podem influenciar bastante os resultados de solubilização em ácido ć́trico. Uma análise morfológica da apatita, eventualmente presente nos produtos obtidos, pode trazer informaçóes sobre a efetividade dos processos de fusão e resfriamento rápido.

Abstract: Fused potassic termophosphate was produced in laboratory starting from the phosphatic rock from Irece (BA), the syenite from Triunfo (PE), and the magnesite from Brumado (BA). Solubilization of phosphorus and potassium in citric acid solution (2\%) attained over $90 \%$ in experiments with total $\mathrm{P}_{2} \mathrm{O}_{5}$ and $\mathrm{K}_{2} \mathrm{O}$ contents between 14 and $17 \%$ and 4 and $5 \%$, respectively. The fused potassic termophosphate properties (cristallization of apatite, citric acid solubilization) are controlled by the glass structures which are defined by network former elements, $\mathrm{P}, \mathrm{Si}, \mathrm{Al}$, and $\mathrm{Fe}$. Associated liquid immiscibility phenomena strongly influence the citric acid solubilization results. A morphological analysis of the apatite, occasionally present in the products, can be used to check the effectiveness of fusion and quenching processes.

SOUZA, Agenor Pereira

Mapa geologico na escala 1:50.000 e esboço da evoluçāo tectônica e sedimentar do Grupo Itaiacoca, nas folhas Barra do Chapéu e Ouro Verde-SP/PR. 17 de dezembro. 200p. 1 vol. 
Orientador: Georg Robert Sadowski.

Resumo: Este trabalho propōe a compartimentação litoestratigrafica do Grupo Itaiacoca, nas folhas Barra do Chapéu e Ouro Verde, a SW do Estado de São Paulo e NE do Estado do Paraná.

O Grupo Itaiacoca, uma sequeência sedimentar de idade do Proterozsico inferior a médio, apresenta grau metam6rfico do fácies xistos verdes.

Através de mapeamento geológico em escala 1:50.000 da realizaçâo de perfis litoestratigrafico-estruturais de detalhe e da observaçăo de estruturas geopetalicas, foram reconhecidas e ordenadas quatro unidades litocstratigráficas maiores. Sua correlaçâo lateral é entendida, dentro de evolução paleogeografica da Bacia Itaiacoca, através de grandes eventos de variaçáo relativa do nível do mar.

. Formaçăo Bairro de Estiva, basal ao Grupo Itaiacoca na área mapeada-sequêencia metarrudítica-psamítica continental, provavelmente de leques aluviais e/ou fanglomerados depositados em calhas profundas de um "rift" continental ("grabens"/"horsts");

. Formaçăo Água Nova - sequểncia metapelitica-carbonática transgressiva de plataforma continental interna a externa;

. Formação Serra do Macaco - sequêencia quartzitica regressiva de linha de costa, com termos pelíticos arenosos e transgressivos no topo;

. Formaçảo Bairro dos Campos - seqüência metadolomf́tica de plataforma carbonática com termos impuros arenosos costeiros (setor SE) e pelificos de águas mais profundas (setor NW).

A hierarquizaçäo das estruturas planares e lineares possibilitou o reconhecimento de quatro fases de dobramentos superimpostos sendo duas sin-xistosas $\left(F_{1} \subset F_{2}\right.$ gerando as foliaçōes $S_{1}$ e $S_{2}$, geralmente paralelas a $\left.\mathrm{S}_{0}\right)$; uma tardi-xistosa $\left(\mathrm{F}_{3}\right)$ e uma pós-xistosa $\left(\mathrm{F}_{4}\right)$.

A estruturação da área ocorre através de amplas dobras holomórficas e cilíndricas de $3^{\mathrm{a}}$ geraçấo de flancos normais a ligeiramente assimétricos, que plungeiam para NE e SW. Localmente ocorrem dobras $\mathrm{D}_{2}$ (coaxiais a $\mathrm{D}_{3}$ ) de flanco inverso e predomínio de foliaçáo planoaxial mergulhando para SE. Dobramentos suaves $\mathrm{D}_{4}$ afetam transversalmente as estruturas anteriores produrindo figuras de interferência do tipo "caixa de ovos". Falhamentos dúcteis e rupteis com direçōes NE-SW, E-W e NW-SE completam o arcabouço estrutural da área.

Intrusōes graníticas do Proterozóico Superior, de natureza pré e tardi a pós-colisional são comuns nos metassedimentos e também em rochas do Complexo Granitoide Três Córregos e Cunhaporanga.

O conjunto de evidências enumeradas, sugere para o Grupo Itaiacoca uma evoluçăo de caráter polićclico, entre o Proterozóico Médio e Cambriano Inferior.

Os esforços compressivos da $3^{4}$ e $4^{4}$ fase de dobramentos podem ser relacionados a um episodio de colisão continental, entre o Proterozoico Superior e o Cambriano Inferior. Isto remete as primeira c segunda fases de deformagăo a eventos anteriores à colisão, talvez ocorridos $\mathrm{cm}$ margem continental do tipo Cordilheirano no Proterozbico Medio.

Abstract: Geological mapping on a scale of 1:50,000, plus lithoestratigraphic and structural analysis, has led to the formal stratigraphic subdivision of the metasedimentary rocks of the Itaiacoca Group, southwestern State of Săo Paulo and northeastern State of Paraná, Brazil.

The Itaiacoca Group consists of a lower to middle Proterozoic sedimentary sequence exhibiting greenschist facies metamorphism. 
Four main lithoestratigraphic units are proposed and they are understood to represent different stages in the paleogeographic evolution of the Itaiacoea basin. They are, from the base upwards: . Bairro da Estiva Fm. - a psammitic to rudaceos continental sequence related to alluvial fans and/or fanglomerates deposited in deep grabens asssociated with continental rifting.

. Água Nova Fm. - a pelitic to carbonatic sequence becoming more psammitic (siliciclastic), interpreted as representing progressive internal to external shelf sedimentation during a rise in sea level.

- Serra do Macaco Fm. - a predominantly quartzitic sequence deposited under regressive shoreline conditions with an increase up wards in pelitic sediments possibly due to a new rise in relative sea level.

. Bairro dos Campos Fm. - a dolomitic carbonate shelf sequence, with shoreline dolostones in the SE sector and deeper shelf dolomudstones in the NW sector.

Four-phases of folding have been identified: the first and second were linked to metamorphic phenomena; the third occurred during late-metamorphism; and last was pos-metamorphic. The main structural framework of the area reflects the holomorphic folding of the third phase. These folds are cylindrical with normal to asymmetric limbs, and NE- to SW-plunging axes. Second-phase folds are locally coaxial with third-phase folds. They have inverted limbs and plan-axial foliation with SE dips.

Four-phase folds are open and transverse to earlier structures which results in type 1 interference patterns. Fault zones exhibit ductile and ruptile behaviours and NE-SW, E-W, and NW-SE strike directions.

Pre and late-to post-collisional granitic bodies, late Proterozoic in age, are intrusive into metasedimentary rocks and Três Córregos, Cunhaporanga Granitic Complex. Also the third and fourth folding phases are related to continental collision events, at the late Proterozoic to the early Cambrian age. Earlier first and second phases are more property related to previous tectonic events, like cordillera subduccion during the Middle Proterozoic.

\section{YOSHINAGA, Sueli}

Estudos hidrogeologios, hidrogeoquimicos $e$ isotopicos das águas minerais e termais de Águas de Lind6ia, SP. 15 de maio. 124p. 1 vol. Orientador: Annkarin Aurelia Kimmelmann e Silva.

Resumo: As famosas "águas minerais" dos municipios de Águas de Lindóia c Lindóia tĉm sua circulaçấo condicionada aos fraturamentos das rochas pertencentes ao Complexo Amparo.

Os estudos da geologia e sua história evolutiva são importantes para o melhor entendimento da origem, dos mecanismos de circulaçâo e mineralizaçăo das águas exploradas na área. Desta forma, as direçōes de fraturas de maior ocorrência e aquelas que se encontram abertas são definidas, atraves de análise de fraturamento, e correlacionadas com as tendências de maior capacidade especifica c vazão.

As análises quimicas das águas das fontes e poços tubulares indicam baica mineralização, com teores de STD em torno de $100 \mathrm{mg} / \mathrm{L}$. Estas classificam-se, principalmente, como bicarbonatadas mistas e calcicas, caracterizando águas enriquecidas de elementos provenientes dos processos de alteraçáo de minerais silicatados de rochas de composiçäo granítica. A hidrólise é o principal processo modificador das águas, seguida secundariamente pelos processos de troca de bases e oxi-reduçâo. Através das relações hidroquímicas nota-se que estas águas possuem curto tempo de residência.

Os valores dos isótopos de $\delta^{18} \mathrm{O}$ e $\delta^{2} \mathrm{H}$ apontam a origem meteórica destas águas e áreas de recarga diferentes, bem como detectam o fenômeno da evaporaçāo, indicando a influência climática nas águas da área. 
A monitoração dos pontos selecionados determinou que alguns elementos ou parâmetros físico-químicos possuem correlação direta ou inversa com os indices pluviométricos e outros parecem estar sob influência dos processos de alteraçã̃o.

No tocante ao Código de Águas Minerais (decreto lei $n^{\circ} 7841$ de 08/08/45), este está sendo reestruturado e atualizado, face ao desenvolvimento tecnol6gico e cientifico adquirido nestes 45 anos. Todavia, neste trabalho se discute o uso da radioatividade do gás radônio- $2 m$ como parâmetro classificatorio de águas minerais, devido a sua natureza instável e periculosidade a saúde humana.

Abstract: The underground circulation of the so-called "mineral waters" of Aguas de Lind6ia and Lindoia is conditioned by fractures of Complex Amparo crystalline rocks.

The geologic studies and its cvolutionary history are so important for understanding the origin, circulation and mineralization of these explored waters.

The analysis of the fractures pointed to the most frequent directions and to the orientation of the opened ones. These are important parameters for knowing the highest values of water discharges and specific capacities.

The chemical analysis of the waters both from springs and wells pointed to low mineralization with about $100 \mathrm{mg} / \mathrm{l}$ TDS. The bicarbonated calcic and calcic-magnesian content was interpreted as coming from alteration processes of silicate minerals. Hydrolisis is the most important alteration process following by the ionic exchange and oxi-reduction. The waters has low residence time too. The isotopes $\delta^{18} \mathrm{O}$ and $\delta^{2} \mathrm{H}$ concentrations indicate the meteoric origin, diferent recharge zones and evaporation phenomena in the springs and wells waters on the study area.

The select points of monitoration determine that some elements or parameters has direct or inverse correlation with the pluviometric values. Uncorrelated parameters and elements resulted from alteration processes.

The "Codigo de Águas Minerais" (August $8^{\text {th }}, 1945$ ) are now being reestructured and put upto-date, in view of the advanced tecnological and scientific development in the last 45 years. The Radon- 222 radioactivity used to classification of mineral waters in this legislation is dubious because it is unstable $(3,82$ days) and may be dangerous to human health. 